\title{
Scan: perfil de desempenho em crianças de sete e oito $\operatorname{anos} * * * * * * *$
}

\section{Scan: performance profile of children with seven to eight years}

\author{
Priscila de Araújo Lucas* \\ Carolina Chibene Zacare** \\ Orozimbo Costa Alves Filho*** \\ Regina Célia Bortoleto Amantini**** \\ Maria Cecília Bevilacqua***** \\ Elena Zaidan******
}

*Fonoaudióloga. Mestranda do Departamento de Fisiopatologia Experimental da USP. HRAC - USP Bauru. Docente da UNIVAC - MT Endereço para correspondência: Rua Barão Demelgaço, 50 - B1. 5 - Apto. 203 - Porto - Cuiabá - MT - CEP 78025-300 (prilucas@hotmail.com).

**Fonoaudióloga do Hospital de Base de São José do Rio Preto. Especialista em Audiologia Clinica e Educacional no HRAC - USP - Bauru.

***Médico Otologista. Professor Livre Docente do Departamento de Fonoaudiologia da FOB - USP.

*****Fonoaudióloga. Professora Doutora do HRAC - USP - Bauru

*****Fonoaudióloga. Professora Titular do Departamento de Fonoaudiologia da FOB - USP Coordenadora do Programa de Implante Coclear do HRAC - USP.

******Fonoaudióloga. Doutoranda do Departamento de Distúrbios da Comunicação pela University of Massachusetts-Amherst.

********Pesquisa Realizada no Centro de Pesquisas Audiológicas do HRAC USP - Bauru.

Artigo Original de Pesquisa

Artigo Submetido a Avaliação por Pares

Conflito de Interesse: não

\section{Abstract}

Background: the assessment of the auditory processing is a useful procedure to detect deficits not only related to sound reception but also to the analysis and organization of sound information, which in turn leads to a therapeutic process that aims at the maximization of communication. Aim: to characterize normal score patterns in a auditory processing screening test, applied in 40 children with ages varying from seven to eight years and to compare the results of the present study to those in the national literature. Method: 40 normal hearing children, students of regular schools of Bauru-SP, who presented no signs of auditory processing disorder, were evaluated. Results: the average scores obtained for children with seven years of age in the subtests of filtered speech, speech in noise and competing words were of $33.35,32.5$, and 71.8 respectively, and for children with eight years of age the scores were of 33.5, 34.5 and 79.9. Conclusion: the significant statistical differences found between the analyzed studies indicate the need of studies involving a larger number of children of different geographic and social areas.

Key Words: Child Development; Auditory Perception; Hearing.

\section{Resumo}

Tema: avaliar o processamento auditivo é um procedimento muito útil para detectarmos alguma alteração no processo não apenas de recepção, mas também análise e organização da mensagem sonora, e também para trazer um norteador para o processo terapêutico fonoaudiológico que visa à maximização da efetividade da comunicação. Objetivo: caracterizar o padrão de normalidade da pontuação em teste de triagem de processamento auditivo, aplicado em quarenta crianças de sete e oito anos e comparar os achados do presente estudo com a literatura nacional. Método: foram avaliadas quarenta crianças portadoras de audição normal, sem indicativos de distúrbio do processamento auditivo e pertencentes à rede regular de ensino de Bauru-SP. Resultados: a pontuação média obtida na idade de sete anos nos sub-testes fala filtrada, fala no ruído e palavras competitivas foi de 33,35; 32,5 e 71,8 respectivamente, e nas crianças de oito anos foi de 33,5; 34,5 e 79,9. Conclusão: as diferenças estatisticamente significantes encontradas entre os estudos analisados mostram a necessidade de um trabalho que avalie um maior número de crianças de regiões geográficas e sociais diferentes.

Palavras-Chave: Desenvolvimento Infantil; Percepção Auditiva; Audição.

Recebido em 24.10.2006.

Revisado em 01.03.2007; 24.07.2007;

14.08.2007; 06.11.2007.

Aceito para Publicação em 06.11.2007.

Referenciar este material como:

1 Lucas PA, Zacare CC, Alves Filho OC, Amantini RCB, Bevilacqua MC, Zaidan E. Scan: performance profile of children with seven to eight years (original title: Scan: $\Sigma 3$ perfil de desempenho em crianças de sete e oito anos). Pró-Fono Revista de Atualização Científica. 2007 out-dez;19(4):370-3. 


\section{Introduction}

Auditory Processing (AP) can be defined as the complex processing of sounds after the initial sonic energy transduction by the auditory nerve... the process can be characterized as the representation of frequency and temporal auditory patterns used to identify and locate sounds. 1

The auditory processing disorder (APD) is closely related to learning disabilities or school deficits as inadequate sound processing can lead to alteration of speaking perception creating difficulties in language learning development and consequently generating learning disabilities. 2,3,4,5 Individuals having this disorder can show orthographic, reading and writing disabilities, difficulties with certain phonemes and also foreign language learning problems. 6,7

At present, there is a need to standardize tests that evaluate AP which have already been translated to Portuguese to enable education professionals make use of such resource to help children with learning difficulties originated in APD. In 2001, Zaidan adapted an AP screening test called SCAN (Screening Test for Auditory Processing Disorders) which aims at evaluating pre-primary and primary school children to detect early APD. 8

Hence the need of this work to support an analysis of the Portuguese Language applied to a greater number of children so as to enable the earliest possible APD detection and intervention, preventing psychological damages to potential children likely to develop such disorder.

\section{Method}

The aim of the present work is to determine the normality pattern in the SCAN Central Auditory Processing Test applied to seven-to-eight-year-old children, besides comparing the present findings with the ones found in Zaidan's work 8 and check the error and correction rate for each word in the test.

This research has been approved by the Ethics and Human Being Resource Committe of the Hospital de Reabilitação de Anomalias Craniofacias (Craniofacial Anomalies Rehabilitation Hospital) of the University of São Paulo - Bauru, as reported in the record n ${ }^{\text {o: }}$ 049/2006-UEP-CEP. The people responsible for the evaluated children have signed a free and detailed consent term.

Twenty seven-year-old and eight-year-old children were selected, therefore an overall number of 40 children, having the folowing profile: tone auditory threshold up to 15 dBNA, absence of fonological alterations, absence of auditory processing disorder background, high middle socio- economical level, studying in private schools in Bauru-SP, right-handed, both male and female.

For these children to become eligible, their parents were argued by means of a questionnaire containing questions suggesting that the child might be a potential candidate to APD. All the children were subject to an evaluation of their own phonological abilities by means of a Phonological Abilities Profile test 9, that might detect a linguistic alteration likely to jeopardize the result and the analysis of the AP exam. An auditory screening was made, researching the thresholds in the frequency ranging from 500 to $4000 \mathrm{~Hz}$ by air, using the audiometer model MIDIMATE 622, MADSEN Eletronics and earphones type Audiocups, made by Amplivox.

Then the 20 children in each age range to be submited to AP evaluations using the audiometer connected to the Compact Disc Player (CDP) model PD P30, portable, made by TEAC were selected. The SCAN Test consists of three subtests: Filtered Words, Auditory Figure Ground and Competing Words

All the evaluations were done in silent rooms at the school premises. The AP exam tests had been recorded in a $\mathrm{CD}$ by a professional speaker that narrated the instructions and the lists of words used in each subtest, issued at the intensity of $60 \mathrm{dBNA}$.

The collected data were analyzed by means of an average score to describe the results of the average range between the participants, as well as, the parameters of minimum and maximum obtained values. The Mann-Whitney Test was used for inferential statistics with a level of significance of $5 \%$.

\section{Results}

The duration of the SCAN Test application was approximately 20 minutes. The average, median, minimum and maximum values of the socores found in the age range of seven and eight in the subtests of Filtered Words, Auditory Figure Ground and Competing Words, as well as in the SCAN total score are summarized on Table 1.

The $p$ values obtained by the comparison of the results between the age groups of seven and eight in the tests of Filtered Words, Auditory Figure Ground, Competing Words and Total Score in the present study and in Zaidan's work8 are showm on Table 2.

The values obtained by comparing Zaidan's results 8 with the ones of the present study among the seven and eight-year-old groups in the subtests of Filtered Words, Auditory Figure Ground, Competing Words and Total Score are shown on Table 3.

An error and correction percentage analysis of each word contained in the SCAN Test has been carried out, and words of high error and correction range have been found. 
TABLE 1. Statistical analysis of scores found in SCAN subtests.

\begin{tabular}{l|cccccccccccccccc}
\hline & \multicolumn{1}{c|}{ Average } & \multicolumn{4}{c}{ Median } & \multicolumn{4}{c}{ Minimum } & \multicolumn{4}{c}{ Maximum } \\
\hline & FW & AFG & CW & TS & FW & $\begin{array}{c}\text { AF } \\
\text { G }\end{array}$ & CW & TS & FW & AFG & CW & TS & FW & ACG & CW & TS \\
\hline 7 year-olders & 33.35 & 32.5 & 71.8 & 136.1 & 34.5 & 33.0 & 75.0 & 139.0 & 23.0 & 25.0 & 41.0 & 93.0 & 39.0 & 38.0 & 90.0 & 161.0 \\
\hline 8 year-olders & 33.5 & 34.5 & 79.9 & 147.9 & 35.0 & 34.5 & 80.5 & 149.5 & 20.0 & 29.0 & 57.0 & 124.0 & 39.0 & 37.0 & 93.0 & 166.0 \\
\hline
\end{tabular}

Legend: FW Filtered Words, AFG Auditory Figure Ground, CW Competing words, TS Total Score.

TABLE 2. Statistical Analysis by Mann-Whitney test comparing 7 and 8 age groups.

\begin{tabular}{|c|c|c|c|c|}
\hline$\underline{\text { Subtests }}$ & $\begin{array}{l}\frac{\text { Filtered }}{\text { Words }} \\
\underline{\underline{y}}\end{array}$ & $\begin{array}{l}\frac{\text { Auditory }}{\text { Figure }} \\
\text { Ground }\end{array}$ & $\frac{\text { Competing }}{\underline{\text { Words }}}$ & Total Score \\
\hline $\begin{array}{l}\text { P-Value - } \\
\text { Present study }\end{array}$ & 0,806 & 0,038 & 0,047 & 0,048 \\
\hline$\frac{\frac{\text { P-Value- }}{\text { Zaidan }}}{\underline{\text { (2001) }}}$ & 0,0913 & 0,396 & 0,287 & 0,048 \\
\hline
\end{tabular}

TABLE 3. Statistical Analysis by the Mann-Whitney Test comparing the present word and Zaidan's (2001).

\begin{tabular}{|c|c|c|c|c|}
\hline Subtests & $\begin{array}{l}\text { Filtered } \\
\underline{\text { Words }}\end{array}$ & $\frac{\text { Auditory Figure }}{\text { Ground }}$ & $\frac{\text { Competing }}{\underline{\text { Words }}}$ & $\frac{\text { Total }}{\text { Score }}$ \\
\hline$\frac{\text { P-Value }}{7 \text { year- }}$ & 0,214 & 0,1006 & 0,0017 & 0,0313 \\
\hline $\begin{array}{l}\text { P-Value } \\
\text { 8 year- } \\
\text { olders }\end{array}$ & 0,689 & 0,753 & 0,0173 & 0,089 \\
\hline
\end{tabular}

\section{Discussion}

The descriptive analysis allows us to observe that the average value found in the subtests of Filtered Words and Auditory Figure Ground in seven and eight year-old children in the present study corroborate with the ones found in Zaidan's work 8 as opposed to the score found in the Competing Words subtest. The low score found in the Competing Words resulted in a low total score in the seven and eight-year-old range when compared with the one obtained by Zaidan 8 . The present descriptive data are also in accordance with Amos and Humes 10.
The individual performance differences found in the age groups tested, as well as concerning the works published before and the results obtained by means of comparison of prior studies help to emphasize the importance of researches aiming at evaluating children from different geographic and socio-cultural regions in our country to enable a scoring standardization in screening or diagnosis tests applied to Brazilian children.

The scoring differences statistically significant found in the subjects tested in this work show the need to perform a holistic diagnosis with a 
complementation in the results of certain exams to prevent a fake positive result. According to Woods, Pena e Martin 11 the individual results obtained by groups of diverse ethnics and social level must be interpreted with caution to avoid exposing children to unnecessary evaluations, as well as spare the parents from the anxiety created upon a false diagnosis.

In a comparative study between the score obtained upon the application of SCAN in children born and living in the United Kingdom and in American children it has been observed that the results are not valid for both groups, a fact that stimulates a future study of standardization of performance for the SCAN test applied to children born in different locations. 12.

In Zaidan's study 8 there was no occurence of error rate higher than $50 \%$ per word, nor correction rate of $100 \%$. In the present study few words with $100 \%$ correction or more than $50 \%$ error were found. The present data corroborate with Simon's findings 13 who has also shown the adequation of the SCAN Test adapted to the Portuguese Language as there were few words with a high rate of errors or corrections.

There was a greater number of words with $100 \%$ of correction in the eight-year-old age range in the

\section{References}

1. Griffiths TD. Central auditory processing disorders. Curr. Opin. Neurol. 2002 feb;15(1):31-3.

2. Fellipe ACN, Colafêmina JF. Avaliação simplificada do processamento auditivo e o desempenho em tarefas de leitura-escrita. Pró-Fono Revista de Atualização Científica. 2002 maio-ago;14(2):225-40.

3. King C, Warrier CM, Hayes E, Kraus N. Deficits in auditory brainstem pathway encoding of speech sounds in children with learning problems. Neuroscie. Lett. 2002 feb;319(2):111-15.

4. King WM. Comorbid auditory processing disorder in developmental dyslexia. Ear Hear. 2003;24(5):448-56.

5. Sauer L, Pereira LD, Ciasca SM, Pestun M, Guerreiro MM. Processamento auditivo e SPECT em crianças com dislexia. Arq. Neuro-Psiquiatr. 2006 mar 64(1):108-11.

6. Capovilla FC. Triagem de processamento auditivo central em crianças de 6 a 11 anos. Rev. Bras Crescimento Desenvolv Hum. 2002 jul-dez;12(2):23-38

7. Tristao R, Feitosa MAG. Speech perception in infants in their first year of life. Estud. psicol.[artigo na Internet]. 2003 [acessado em 14 ago. 2006];8(3). Disponível em:

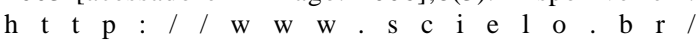
scielo.php?script $=$ sci_arttext \& pid $=$ S 1413 $294 X 2003000300013 \& \operatorname{lng}=\mathrm{en} \& n r m=$ iso
Filtered Words and Competing Word subtests, showing that the age growth allowed some improvement in the processing capacity of the presented sounds. This finding can be justified by the maturing process of the auditory system that occurs progressively and gradually during life. 14

Then the proposal is that the SCAN Test should be applied in a wider range of cases including subjects with and without APD so that the sensitivity and specification of this test can be evaluated as well as the error and correction rate of the words used in a population whose mother tongue is the Portuguese.

\section{Conclusion}

The average values of the scoring that characterizes the normality pattern of the studied population were $33.35,32.5,71.8$ e 136.1 scores in the Filtered Words, Auditory Figure Ground and Competing Words and Total Score in the SCAN Test among seven-year-old children and 33.5, 34.5, 79.9 e 147.9 scores among eight-year-old children.

There were words with a high error and correction rate, which suggests a more diversified and broader range of case study.

8. Zaidan H. Desenvolvimento de uma - bateria de testes de triagem auditiva central em pré-escolares e escolares na faixa etária de 6 a 11 anos [dissertação]. São Paulo: Universidade de São Paulo; 2001.

9. Carvalho IAM, Alvarez AMMA, Caetano AL. Perfil de habilidades fonológicas. São Paulo: Via Lettera,1998.

10. Amos NE, Humes LE. Scan test-retest reliability for first and third grade children. J.Speech Lang Hea Res. 1998 aug;41(4):834-45.

11. Woods AG, Peña ED, Martin FN. Exploring possible sociocultural bias on the SCAN-C. Am J Audiol. 2004 dec; 13:173-84.

12. Marriage J; King J; Bringgs J; Lutman ME. The reliability of the Scan test: results from a primary school population in the UK. 2001;35:199-208.

13. Simon LF. Aplicabilidade de uma bateria de triagem do processamento auditivo em escolares com idades entre $8 \mathrm{e}$ 10 anos [dissertação]. Rio Grande do Sul: Universidade Federal de Santa Maria; 2006.

14. Neves FI, Schochat E. Maturação do processamento auditivo em crianças com e sem dificuldades escolares. PróFono Revista de Atualização Científica. 2005 septdec;17(3):311-20. 